\title{
THE EFFECT OF COLLABORATIVE LEARNING STRATEGY AND LEARNING MOTIVATION OF LEARNING RESULTS ISLAMIC EDUCATION OF ISLAMIC ELEMENTARY SCHOOL STUDENTS STATE 057212 KECAMATAN HINAI LANGKAT REGENCY
}

\author{
Rabiatun Adawiyah* \\ *Teacher in Langkat Regency, North Sumatra
}

\begin{abstract}
The objectives of this research were to find out: (1) the different effect between colaborrative and competitive instructional strategy toward Islamic Education achievement, (2) the difference of the Islamic Education achievement between student with high learning motivation and low learning motivation, and (3) the interaction between instructional strategy and learning motivation toward Islamic Education achievement. The population of this research was all students of Grade V SDN 057212 Hinai consisting of two classes. The sampling technique applied was cluster random sampling taught with colaborrative instructional strategy and the students taught with competitive instructional strategy. The instrument used to measure the Islamic Education achievement was a multiple choice test. The instrument used to measure the students' learning motivation was questionnaire. The normality test used Liliefors and the homogeneity test was Fisher test and Bartlett test. The data analysis technique was Analysis of Variance with two-way at the level of significance $\alpha=0,05$ followed by Scheffe test. The research findings were: (1) on average the students' Islamic Education achievement taught with colaborrative instructional strategy was higher than the average the students' Islamic Education achievement taught with competitive instructional strategy, , (2) on average the student' Islamic Education achievement with high learning motivatione was higher than the student' Islamic Education achievement with low learning motivation, and (3) there was an interaction between instructional strategy and learning motivation toward Islamic Education achievement.
\end{abstract}

\section{Keywords: Collaborative Learning, Learning Motivation}

\section{INTRODUCTION}

Islamic Education Learning so far has been too influenced by instant view that is ready to use. This view encourages teachers to be inclined to tell the concept, even though Islamic Religious Education material on Friday prayers and plural prayers, demands that delivery is not dominated only through the delivery of concepts. In other words, the 
learning of Islamic Religious Education is focused on the teacher. In collaborative learning, students are asked to discover their own knowledge by engaging in groups in a meaningful learning process. The role of the teacher is mainly as a guide and facilitator for students in the process of reconstructing ideas and concepts of Islamic Religious Education. The role of the teacher here changes from a validator to a mentor who appreciates each student's work and answers.

One effort that can be done to improve learning outcomes is to improve the quality of learning by implementing better learning strategies. Learning activities are the core of the educational activity itself which is inseparable from the role of the teacher. The ability of teachers to master the design of learning to plan, design, implement and evaluate and conduct feedback is an important factor in achieving learning objectives. The ability of teachers to master learning materials, teaching styles, use of media, determining strategies and choosing learning methods is an effort to expedite the learning process and improve learning outcomes.

The selection of the right learning strategy is absolutely necessary, however the acquisition of Islamic Religious Education student learning outcomes is also influenced by the characteristics of the students themselves, namely motivation to learn, for example in a collaborative learning process, a teacher should be able to know and understand the characteristics of student motivation to learn. By knowing the level of student motivation to learn, a teacher can adjust, compile and make relevant teaching material to help and direct students' readiness to accept subject matter in collaborative learning and competitive learning.

\section{THEORITICAL REVIEW}

Learning outcomes are the result of an interaction of learning and teaching actions (Dimyati and Mudjiono, 2003: 3). Usually learning outcomes are obtained from assessments that can not be separated from the overall implementation of education. The basic assumption is that the optimal teaching process allows optimal learning outcomes. The greater the effort to create the conditions of the teaching process, the higher the yield or product of the teaching.

Djamarah and Zain (2002: 59) explain that learning outcomes are students' mastery of the material / subject matter that the teacher has provided when the teaching process takes place. Gagne and Briggs in Sudjana (2002: 45) suggest that learning outcomes can be grouped into five categories, namely intellectual skills, cognitive strategies, verbal information, motor skills and attitudes. Rohani and Ahmadi (2005: 169) say that the assessment of learning outcomes aims to see the progress of student learning in terms of mastery of teaching material that has been learned in accordance with the objectives set. 
Bloom in Sudijono (2008: 49) states that learning outcomes can be categorized in three domains, namely: (1) cognitive includes educational goals regarding memory or introduction to knowledge and the development of intellectual abilities and thinking skills that are divided into six levels, namely: knowledge (knowledge), understanding (comprehension), application (application), analysis (analysis), synthesis (synthesis), and assessment (evaluation), (2) affective with regard to interests, attitudes and values as well as the development of rewards and adjustments that are shared five levels, namely: acceptance (reception), responding (responding), assessing (valuing), organizing (organization), and characterization (characterization), and (3) psychomotor namely: perception, readiness, guided movements, movements accustomed, complex movements, complex movements , adjusting movement patterns, and creativity.

Learning strategies are specifications for selecting and ordering learning events and activities (Seels and Richey, 1994: 87). Wena (2009: 9) describes learning strategies as a general pattern of teacher and student actions in the realization of learning activities, while learning delivery strategies are steps used to convey learning to students and / or to receive and respond to student input.

Miarso (2004: 530) states the learning strategy is an overall approach to learning in a learning system in the form of general guidelines and a framework of activities to achieve the general objectives of learning, which are elaborated from the view of certain philosophies or theories of learning. Meanwhile Suparman (2012: 241) states that the learning strategy is an approach in managing the content and learning process comprehensively to achieve one or a group of learning goals.

Hamalik (2004: 2) defines a learning strategy as a whole method and procedure that focuses on student activities in the teaching and learning process to achieve certain goals. In the context of learning strategies structured objectives to be achieved, the material to be studied, learning experiences and evaluation procedures.

Mudhoffir (1993: 23) explains that the understanding of learning strategies is a little broader because it also includes the understanding of teaching approaches in delivering information, selecting teaching support sources and determining and explaining the role of students in developing learning programs that pay attention to students' environmental conditions so that the learning process becomes more effective.

Santoso (2013: 16) explains collaborative learning is a situation where two or more people learn or try to learn something together. In contrast to self-study, people involved in collaborative learning make use 
of the resources and skills possessed by others in their groups, such as asking for information, evaluating ideas, monitoring each other's work.

Gunawan (2004: 187) states that there are five important elements that must exist in collaborative learning, namely: (1) positive interdependence (feelings of togetherness), (2) face-to-face interaction or face-to-face interaction (mutual help, mutual respect, congratulating and celebrating mutual success, (3) individual and group responsibility for learning success, (4) interpersonal communication skills and communication in a small group (communication, trust, leadership, decision making and management and conflict resolution, and (5) group processing (reflecting on their functions and abilities to work together as a group and how to be able to perform better).

Yenni (2015: 57) explains the steps of collaborative learning are: (1) before students gather according to their respective groups, the teacher explains the material summary of about 10-15 minutes, (2) the teacher invites students to gather according to their respective groups, (3) all groups are told to complete the tasks in the worksheets until the coverage of certain materials in accordance with the allocation of time provided, (4) each student discusses and exchange opinions to formulate answers, (5) one of the group members assigned write answers that have been mutually agreed upon, (6) the teacher collects the reports of each group, (7) at least after two or three worksheets are finished being discussed, the teacher gives a quiz one or two questions taken from the worksheet or a self-made question for time allocation 10 minutes, (8) student reports corrected, commented, assessed, returned to the next meeting, and discussed, and (9) quiz results corrected and listed ar progress experienced by students in the quiz.

Competitive learning strategy is a type of learning strategy in which students learn and complete their tasks individually or independently. Nasution (2000: 87) explains how to adjust individual learning where competitive nuances take place, namely, students accept assignments that are completed according to their own pace, students are given additional assignments, students do things according to their interests and abilities.

The steps of competitive learning are explained by Johnson and Johnson in Azis (2008: 5) as follows: (1) delivery of teaching material, (2) assigning individual assignments, (3) completing assignments, and (4) checking the results of assignments. Therefore, the things needed in competitive learning are: (1) setting goals which then as a condition for the "winner" when it has achieved that goal, (2) helping and encouraging students to work in their own way in achieving that goal, and (3) rewarding students who successfully reach their goals successfully. 
Winkel (2009: 173) explains motivation means the driving force in people who carry out certain activities in order to achieve a certain goal. Meanwhile Sardiman (2010: 38) states learning motivation is a psychological factor that is non-intellectual. It means that learning motivation has a unique role in fostering enthusiasm for learning where students who have strong motivation will have a lot of energy to carry out learning activities. Effort or driving force is a form of readiness or a tendency of energy changes in a person to carry out activities that aim. The goals that underlie an activity are generally urgent or highly felt.

Hamalik (2004: 166) states that there are many ways to foster motivation in learning activities, namely: (1) giving numbers, (2) praise (3) prizes, (4) group work, (5) competition, (6) goals and level of aspiration, (7) sarcasm, (8) assessment, (9) field trips and excursions, (10) educational films, and (11) learning through the radio. Growing motivation to learn is not easy, therefore teachers are very important to know the characteristics of their students, and have the creative ability to design learning according to the needs and interests of students so that their motivation to learn increases.

\section{METHODS}

The research method used is quantitative correlational type. The population in this study were all fifth grade students of SDN 057212, Hinai Subdistrict, Langkat District, 2017/2018 academic year consisting of 2 (two). The research sample was assigned one class as a collaborative learning class and one competitive learning class. The sampling technique is done by cluster random sampling. The research instruments were tests and questionnaires. The test is used to obtain data on learning outcomes while the questionnaire is used to see the characteristics of student motivation. Test the normality with the Liliefors test while the homogeneity test with the Fisher test and the Bartlett test. The analysis technique is two-way Anava at the significance level $a=0.05$ followed by the Scheffe test.

\section{RESEARCH RESULTS AND DISCUSSION}

The results of this study have shown that the group of students of SDN 057212 Hinai Subdistrict, Langkat District who were taught with collaborative learning strategies obtained higher Islamic Religious Learning outcomes than groups of students taught by competitive learning strategies, where the average value of Islamic Religious Education learning outcomes obtained by students of SDN 057212 Hinai Subdistrict, Langkat District who were taught with collaborative learning strategies were higher than students who were taught with competitive learning strategies. These findings indicate that to teach Islamic Religious 
Education material it is more appropriate to use collaborative learning strategies than with competitive strategies.

The first hypothesis stating Islamic Religious Education learning outcomes among students of SDN 057212 Hinai Subdistrict, Langkat District who were taught with collaborative learning strategies were higher than student learning outcomes who were taught with competitive learning strategies. This is understandable because through collaborative learning strategies can encourage students to actively learn as explained by Jonassen (1996) that collaborative learning is a small group learning where students work together to maximize their own learning outcomes and the learning outcomes of other group members. The collaborative learning process is not just working together in a group but the emphasis is more on a learning process that involves the communication process as a whole and fair in the classroom.

In addition, collaborative learning strategies aim at fostering student participation in doing the exercises proposed by the teacher in learning, fostering discussion among students in finding causes and solutions to these issues or problems. Therefore the teacher's role in collaborative learning as a facilitator directs students to find and construct their own knowledge.

Collaborative learning strategy is a strategy in learning in the form of learning groups that work together. Therefore, in collaborative learning interaction, cooperation and mutual need occur among the members of the learning group. The measure of success is determined based on the extent to which the study group achieved the goal. In this activity, cooperation, personal responsibility and mutual support are needed because the success of the group is determined by the success of the individual members involved in it.

On the other hand, competitive learning strategies strongly emphasize personal effort to achieve the goals set. Interaction between friends is very less and each individual is oriented towards achieving maximum results. The assessment and reward system becomes a reference for determining the loss and loss of a person in achieving the targets set.

Implementation of Islamic Religious Education learning by implementing collaborative learning strategies, the teacher's role is to facilitate the division of learning groups, giving group assignments which of course begins with the presentation of important points of teaching material. Then the students then interact in their groups and create positive interdependence among students, the division of work and responsibilities are well established.

Implementation of Islamic Religious Education learning by implementing competitive learning strategies the role of the teacher is the main deliverer of teaching material then students are given individual 
assignments. During the learning process individually students work preparing their assignments. Therefore there is less interaction between students and there is no division of labor, so the work of students is individual work. Therefore for students who are smart do not experience difficulties in completing these tasks, while for students who are slow will certainly have difficulty in completing assignments.

Collaborative learning strategies make it possible for students to learn to understand the subject matter of Islamic Religious Education because it is carried out in a joint learning community among students. Students in collaborative learning activities can learn together to solve problems or solve tasks together, students who lack understanding of Islamic Religious Education subject matter can ask their friends who are more proficient. Whereas in competitive learning, students learn individually, therefore if students have difficulty in solving problems or completing assignments then these students experience difficulties because other students provide less support or assistance.

The above statement is in line with Davis's (1993) study of collaborative strategies, namely: (1) students work in teams to master subject matter, (2) teams or groups are formed varying from students who have high, moderate, and low academic performance, (3) the team consists of members who vary in terms of gender, and race, and (4) the reward system is oriented towards groups, not individuals, while Hill and Hill (1996) that there are two important elements that are always present in collaborative activities namely the common goals and positive interdependence. \If it is further noted that in collaborative learning strategies the average learning outcomes of Islamic Religious Education students with higher learning motivation than student learning outcomes with low learning motivation. Whereas in competitive learning strategies, the average learning outcomes of Islamic Religious Education students with low learning motivation is higher than the results of Islamic Religious Education students with high learning motivation.

This shows that the ability to learn motivation is significant enough to differentiate student learning outcomes, where the learning outcomes of students with high learning motivation are more precisely taught by collaborative learning strategies while students with low learning motivation skills are more precisely taught with competitive learning strategies.

The second hypothesis testing shows that learning outcomes of students with high learning motivation are higher than student learning outcomes with low learning motivation. These results prove that learning motivation is significant to distinguish learning outcomes of Islamic Religious Education. Learning motivation in this study is categorized into two categories: high and low. 
The results of overall data analysis obtained average student learning outcomes with high learning motivation better than student learning outcomes with low learning motivation. This indicates that students with high learning motivation on average have better Islamic Learning outcomes than students with low learning motivation. Thus students with high learning motivation better understand and master Islamic Religious Education subject matter than students with low learning motivation.

This is understandable because students with students with high learning motivation characteristics are generally those who are easy to get along with, active, optimistic, passionate, lively, passionate, have empathy, sympathy and high persuasion. While the characteristics of low learning motivation have characteristics such as: difficult to get along, happy to be alone, indifferent, pessimistic, passive, quiet, and difficult to adapt to others. Because of this different characteristic of learning motivation it is predicted to have an influence on the achievement of students' Islamic Education learning outcomes.

Islamic Religious Education learning materials in the form of a set of knowledge, forms of skills and the inculcation of attitudes and values in the context of the discipline of Islamic Education. In addition, the learning of Islamic Religious Education is expected to develop the ability to think that can develop knowledge, skills and attitudes of confidence. Likewise, the learning outcomes of Islamic Religious Education are a picture and level of cognitive ability in the form of knowledge and skills in the form of facts, concepts, procedures and principles.

Noting the learning characteristics of Islamic Religious Education above, the characteristic factors of learning motivation also influence the level of success in achieving the success of Islamic Religious Education learning. As the previous explanation that there are differences in the characteristics of students that affect the development of individual personality including learning motivation. Where students with high learning motivation characteristics are more likely to develop learning success than students with low learning motivation characteristics. Students with high learning motivation characteristics in learning Islamic Religious Education will show a strong urge to be oriented towards achieving the maximum Islamic Learning Education achievement than students with low learning motivation characteristics.

The third hypothesis testing there is an interaction between learning strategies and learning motivation in influencing student learning outcomes in Islamic Religious Education. When seen the average learning outcomes in groups of students with high learning motivation and learning with collaborative strategies are better than the average learning 
outcomes of groups of students with high learning motivation and are taught with competitive learning strategies.

The average learning outcomes of Islamic Education in groups of students with low learning motivation and learning with collaborative strategies is lower than the average learning outcomes of groups of students with low learning motivation and are taught with competitive strategies. This means that for groups of students with low learning motivation it is better to use competitive learning strategies compared to using collaborative learning strategies. Thus it can be concluded that learning strategies and learning motivation significantly influence student learning outcomes in Islamic Religious Education.

Collaborative learning strategies allow students to search for and reconstruct information/knowledge by collaborating or collaborating with classmates. Therefore, collaborative learning is intertwined with the interaction of students with their environment in order to find the widest possible information. This is in line with the expression of Gunawan (2004: 197) that the advantages of collaborative learning are: training caring, caring and willingness to share, increasing respect for others, training emotional intelligence, prioritizing group interests over personal interests, honing interpersonal intelligence, training abilities work together, practice the ability to listen to the opinions of others, conflict management, communication skills, students are not ashamed to ask their own friends, speed and learning outcomes increase, speed and learning outcomes increase rapidly, increased memory of the material being studied, increase motivation and learning atmosphere .

While the weakness of collaborative learning is students who are smarter if they do not understand the real purpose of the learning process then feel disadvantaged because they have to bother helping their friends, smart students will also object because the value they get is determined by the achievements or achievements of their groups, if collaboration cannot be carried out well, only smart and active students will work.

The influence of collaborative and competitive strategies can have variations when viewed from the learning motivation possessed by students. Students with high learning motivation generally are those who are easy to get along with, active, optimistic, passionate, lively, uplifting, have empathy, sympathy and high persuasion. These characteristics are very suitable and develop well if the activities are carried out in groups. That means that the use of collaborative strategies with students who are motivated to learn will have more effective effects and outcomes than the use of competitive strategies. Thus it can be assumed that the effect of cobalorative strategies for student learning outcomes with high learning motivation will be better than the use of competitive strategies. 
Therefore there is a difference in influence between collaborative and competitive strategies on student learning outcomes that are highly motivated learning where collaborative strategies are expected to have a better effect than competitive strategies. Students with low learning motivation have characteristics such as: difficult to get along, happy to be alone, indifferent, pessimistic, passive, quiet, and difficult to adapt to others. These characteristics when given a collaborative strategy that emphasizes collaboration and interaction with other students less influence on them.

Conversely competitive strategies will have a positive impact on those who have low learning motivation. Because it is more aloof and difficult to get along with, the work done will be more effective when done alone than together with others. Therefore, if this type is given a competitive strategy it will have a better effect than the collaborative strategy. Thus it is suspected that there is a difference in the effect of collaborative and competitive strategies on student learning outcomes, where students who are given competitive strategies will be better at spurring the spirit of achievement and the spirit to compete with classmates.

\section{CONCLUSIONS}

The conclusions that can be drawn from the results of the study are: (1) learning outcomes of Islamic Religious Education students of SDN 057212 Hinai Subdistrict Langkat District who are taught with collaborative learning strategies are higher than the average Islamic Religious Education learning outcomes of SDN 057212 SDN 057212 Subdistrict students of Langkat District who are taught with competitive learning strategies. Thus the collaborative learning strategy is more effectively applied in the learning of Islamic Religious Education, (2) learning outcomes of Islamic Religious Education students of SDN 057212 Hinai Subdistrict Langkat District with higher learning motivation compared to the average learning outcomes of Islamic Religious Education SDN 057212 SDN students of Hinai Subdistrict Langkat District with low learning motivation, and (3) there is an influence of interaction between learning strategies and learning motivation, where for students of SDN 057212 Hinai District Langkat District with high learning motivation is more appropriate to use collaborative learning strategies, while SDN 057212 students of Hinai District Langkat District with low learning motivation is more appropriate to use competitive learning strategies.

\section{RECOMMENDATIONS}

The recommendations that can be submitted are: (1) to the Ministry of Religion in Langkat to renew the curriculum if there are no curriculum 
contents on collaborative learning strategies because through this research it is proven that collaborative learning strategies can improve student Islamic Religious Education learning outcomes, (2) to Islamic Religious Education teacher so it is necessary to look at the characteristics of student motivation in implementing learning strategies. Where students with high learning motivation are more appropriate to use collaborative learning strategies and students with low learning motivation then competitive learning strategies should be used for Islamic Religious Education subjects, and (3) to other researchers who wish to further research on collaborative learning strategies and competitive learning strategies should add to the variables controlled so that more knowledge is gained about collaborative learning strategies and competitive learning strategies.

\section{REFERENCES}

Azis, Andi Asmawati., dkk. (2013) Penerapan Pembelajaran Kolaboratif Untuk Meningkatkan Aktivitas Belajar Siswa Kelas XU IPA 3 Melalui Lesson Study Berbasis Sekolah Di SMA Negeri 8 Makassar. Jurnal: Bionature, Volume 14, Nomor 1, April 2013.

Dimyati dan Moedjiono. (2003) Belajar dan Pembelajaran, Jakarta: Rineka Cipta.

Djamarah, Syaiful Bahri. dan Zain, Ahmad. (2002) Strategi Belajar Mengajar. Jakarta: Rineka Cipta.

Gunawan, Adi W. (2004) Genius Learning Strategi. Jakarta: Grasindo.

Hamalik, Oemar. Proses Belajar Mengajar. Jakarta: Bumi Aksara, 2004.

Miarso, Yusufhadi. (2004) Menyemai Benih Tekonologi Pendidikan. Jakarta: Prenada Media Group.

Mudhoffir. (21993) Teknologi Instruksional. Bandung: Remaja Rosdakarya, 1993.

Rohani, Ahmad dan Ahmadi, Abu.(2005) Pengelolaan Pengajaran. Jakarta: Rineka Cipta.

Rusydi Ananda dan Muhammad Fadhli. (2018) Statistik Pendidikan. Teori dan Praktek Dalam Pendidikan. Medan: Widya Puspita.

Santoso, Singgih. (2013) Pengaruh Model Pembelajaran Kolaboratif Dan Motivasi Belajar Terhadap Peningkatan Hasil Belajar Fisika Siswa Kelas X SMA Negeri 1 Purwantoro Wonogiri, Jawa Tengah. Jurnal: Berkala Fisika Indonesia Vo. 5 Nomor 1 Januari 2013.

Sardiman, AM. (2010) Motivasi Belajar Mengajar. Jakarta: Raja Grafindo Persada.

Seels, Barbara. dan Richey, Rita. C. (1994) Instructional Technology, The Defenition and Domains of The Field, Washington. Terjemahan. Yusufhadi Miarso dkk.

Sudijono, Anas. (2008) Pengantar Evaluasi Pendidikan. Jakarta: Raja Grafindo Persada. 
Sudjana, Nana. (2002) Dasar-Dasar Proses Belajar Mengajar. Jakarta; Sinar Baru Algensindo.

Suparman, M. Atwi. (2012) Desain Instruksional Modern. Panduan Para Penajar Dan Inovator Pendidikan. Jakarta: Erlangga.

Wena, Made. (2009) Strategi Pembelajaran Inovatif Kontemporer. Jakarta: Bumi Aksara.

Winkel, W.S. Psikologi Pengajaran. Yogyakarta: Media Abadi, 2009.

Yenni, Agustina. Perbandingan Hasil Belajar Siswa Yang Diajarkan Dengan Menggunakan Model Pembelajaran Kolaborasi Dan Quantum Teaching Pada Materi Pajak Siswa Kelas VIII SMPN 1 Makmur. Jurnal: Sains Ekonomi dan Edukasi Vol. III, No. 1 April 2015 ISSN : 2354-6719. 